\title{
Invasive Ductal Carcinoma, Not Otherwise Specified
}

National Cancer Institute

\section{Source}

National Cancer Institute. Invasive Ductal Carcinoma, Not Otherwise Specified. NCI

Thesaurus. Code C4194.

The most common type of invasive breast carcinoma, accounting for approximately $70 \%$ of breast carcinomas. The gross appearance is usually typical with an irregular stellate outline. Microscopically, randomly arrang ed epithelial elements are seen. When large sheets of malignant cells are present, necrosis may be seen. With adequate tissue sampling, in situ carcinoma can be demonstrated in association with the infiltrating carcinoma. The in situ component is nearly always ductal but occasionally may be lobular or both. 